\title{
Seroprevalence of Hepatitis B Virus Infection (HBsAg) in Rural Blood Donors, Moba, Tanganyika Province, Democratic Republic of Congo (2014 to 2016)
}

\author{
Bukasa Héman Kabemba',2,3*, Ebondo Patrick Kasendue ${ }^{3}$, Muteba André Shiku ${ }^{4,5}$, \\ Tchoni Savant Mukena', Tshinkobo Chicco Kasolva', Nsomue Gentil Kabingie ${ }^{6}$, \\ Kabiswe Joelle Pungue ${ }^{7}$, Tshite John Kitengie ${ }^{3}$
}

\begin{abstract}
${ }^{1}$ Section of Nursing Sciences, Higher Institute of Medical Techniques of Kalemie, Kalemie, Democratic Republic of Congo ${ }^{2}$ Department of Public Health, Faculty of Health Sciences, University Institute of Congo, Moba, Democratic Republic of Congo ${ }^{3}$ Section of Nursing Sciences, Higher Institute of Medical Techniques of Lubao, Lubao, Democratic Republic of Congo ${ }^{4}$ Section of Nursing Sciences, Higher Institute of Medical Techniques of Tshofa, Tshofa, Democratic Republic of Congo ${ }^{5}$ Section of Nursing Sciences, Higher Institute of Medical Techniques of Kamana, Kamana, Democratic Republic of Congo ${ }^{6}$ Department of Internal Medicine, Faculty of Medicine, University of Kabinda, Kabinda, Democratic Republic of Congo ${ }^{7}$ Department of Public Health, Faculty of Medicine, University of Kalemie, Kalemie, Democratic Republic of Congo Email: *hemanuska@gmail.com
\end{abstract}

How to cite this paper: Kabemba, B.H., Kasendue, E.P., Shiku, M.A., Mukena, T.S., Kasolva, T.C., Kabingie, N.G., et al. (2017) Seroprevalence of Hepatitis B Virus Infection (HBsAg) in Rural Blood Donors, Moba, Tanganyika Province, Democratic Republic of Congo (2014 to 2016). Open Access Library Journal, 4: e3434.

https://doi.org/10.4236/oalib.1103434

Received: February 6, 2017

Accepted: March 25, 2017

Published: March 28, 2017

Copyright ( 2017 by authors and Open Access Library Inc.

This work is licensed under the Creative Commons Attribution International License (CC BY 4.0).

http://creativecommons.org/licenses/by/4.0/

\begin{abstract}
Blood transfusion is a salutary practice in modern medicine, but it carries a high risk of transmission of transfusion transmitted infections (TTIs), especially in developing countries. The objective of this study is to determine the seroprevalence of viral hepatitis B among blood donors. This is a retrospective and descriptive cross-sectional study of the period from 2014 to 2016 at the Katele Health Reference Center (Moba, DR. Congo). We investigated HBsAg in blood donors by using Determine ${ }^{\circledR}$ HBSAg. 1145 blood donors with an age mean of $30.6 \pm 6.9$ years and predominantly male $(62.5 \%)$ were retained. The seroprevalence of hepatitis B infection from 2014 to 2016 was 3.9\% (0.3\% for $2014,9.4 \%$ for 2015 and $0.7 \%$ for 2016). The family blood donors (83.2\%) were the only carriers of $\mathrm{HBsAg}$ and were significantly associated with hepatitis B infection $(\mathrm{p}<0.05)$. Age [OR $=0.70$ CI $95 \% 0.34-1.44 ; \mathrm{p} 0.338]$ and sex $[\mathrm{OR}=0.7295 \% \mathrm{CI} 0.27-1.97 ; \mathrm{p} 0.529]$ were not associated with the occurrence of hepatitis $\mathrm{B}$ in blood donors. The risk of transmission of HBV during transfusion remains high. We recommend the strengthening of transfusion safety measures, the abandonment of family donors for regular voluntary donors, the improvement of screening and diagnostic tests, the involvement of the national blood transfusion program in epidemiological surveillance and the mobilization of the population in favor of the fight against hepatitis $B$.
\end{abstract}




\section{Subject Areas}

Hematology, Public Health

\section{Keywords}

Blood Donors, DRC, HBsAg, Hepatitis, Transfusion Safety

\section{Introduction}

Blood transfusion is a salutary practice of modern medicine for the management of severe anemias that urgently need blood [1]. Blood transfusion has been used for more than eighty years and presents risks of transmission of infectious agents transmitted by transfusion [1]-[8]. These agents include the human immunodeficiency virus (HIV), hepatitis B virus (HBV), hepatitis C virus (HCV), hepatitis E virus, Treponema pallidum, Trypanosoma cruzi and brucei (T. brucei brucei and T. brucei gambiense), Cytomegalovirus, Human T lymphocyte virus, etc. [4] [5] [6] [8] [9] [10] [11]. In this study, research is being conducted on the hepatitis B virus (hepatotropic Hepadnaviridae family) in blood donors.

Viral hepatitis B (HVB) is an inflammation of the liver with impairment of hepatocytes that degenerate following infection with hepatitis B virus (HBV) [2] [12]. It is a serious public health problem [2] [12] [13] [14] and patients are at risk of liver cirrhosis and hepatocarcinoma [2] [7] [10] [12] [13] which can lead to hepatic encephalopathy, due to insufficiency Hepatocellular, and death [2] [9] [10] [13]. Around 240 million people are infected with chronic viral hepatitis and more than six hundred and eighty-six thousand individuals die each year as a result of HVB and its consequences [2]. East Asia and sub-Saharan Africa regions are the most affected [2] [15]. HBV is endemic with a different prevalence in different regions of the world [13]. The seroprevalence of markers of hepatitis $B$ virus infection is an indicator that has been variously appreciated among blood donors worldwide: $20 \%$ in Tanzania [16]; in Nigeria $14.0 \%$ in 2000-2013 [17] and $11.1 \%$ in Kano [18]; $10.01 \%$ in Equatorial Guinea [10]; 10.0\% in Cameroon [19]; 4.7\% in Ethiopia [20]; $2.8 \%$ in Rwanda [21]; $1.2 \%$ in Nepal [22]; $1.1 \%$ in India [1] and $0.6 \%$ in Namibia [23], etc.

In the Democratic Republic of Congo, the seroprevalence of hepatitis B virus infection among blood donors is $1.6 \%$ to 9.2\%: Kinshasa 9.2\% [24], Lubumbashi $8.0 \%$ [25] and 6.8\% [6], Kisangani 6.0\% [26], Bukavu 3.7\% [27] and $1.6 \%$ in rural areas of Kamina [28]. In Moba, there are no studies evaluating the seroprevalence of hepatitis B (carriage of HBS antigen) among blood donors. The objective of this study is to determine the seroprevalence of hepatitis B (HBsAg) among blood donors at the Katele Health Center in Moba. It will allow future researchers (local and non-local) and the national blood transfusion program (NBTP) to have a reference in the epidemiological follow-up of HBV infections. 


\section{Materials and Methods}

\subsection{Site, Type and Study Periods}

This is a cross-sectional retrospective and descriptive study carried out at the Katele Reference Center in Moba from 2014 to 2016, i.e. three years. The Katele Reference Health Center (RHC) is located in Moba-Port, in the health area of Moba-Port (population 2017: 25,266 inhabitants), mainly on the shores of Tanganyika Lake, in the health zone of Moba, Province of Tanganyika in the DRC. It covers an estimated population of more than 60 thousand inhabitants, mainly from health areas along Tanganyika Lake (Regezza, Mulunguzi, Kansenge, Liombe, etc.) over a distance of more than $70 \mathrm{~km}$. The main diseases encountered are, in order of importance: malaria, acute respiratory infections, simple diarrhea, dysentery (especially in artisanal mineral extraction areas), measles, cholera (seasonal pattern) and sexually transmitted infections (STI).

The territory of Moba has an area of 24,500 $\mathrm{km}^{2}$ and 609,406 inhabitants, i.e. a density of 24.9 inhabitants $/ \mathrm{km}^{2}$ [29]. The ethnic populations are predominantly Tabwa (over 80\%), Bemba and Luba. There are also other tribes from the DRC and neighboring countries (Tanzania and Zambia). The main activities include agriculture and fisheries. This fishery on Tanganyika Lake attracts people from several towns in the DRC and neighboring countries: Kalemie, Mbuji-Mayi, Kananga, Uvira, Bukavu, Lubumbashi, Kolwezi, Pweto and Kirando (Tanzania). This fishery concerns the species specific to Tanganyika Lake, namely Stolothrissa tanganikae (locally called "DAGA") and Luciolates (locally called "MUKEBUKA").

\subsection{Population and Parameters Studied}

Our study population consisted of all blood donors of the period concerned $(\mathrm{n}=$ 1145). The age, sex, type of blood donation (family, irregular volunteer circumstantial or paid) and the result of the serological investigation of the HBS Antigen were the desired parameters.

\subsection{Method of Determination of Viral Hepatitis B}

The Australian antigen or HBsAg corresponds to the surface antigen of HBV, discovered accidentally by Blumberg in 1964 [13]. It is currently the most widely used serological marker for the diagnosis of acute and chronic HBV infections (presence of HBS Antigen in serum indicates active, acute or chronic viral hepatitis B) and for the screening of blood donors and organs. The title of circulating HBsAg would reflect the amount of DNA-ccd (covalently closed circular deoxyribonucleic acid) present in the liver [13]. HBSAg is the serological marker appearing 1 to 3 months after the contamination and 2 to 4 weeks before alanine aminotransferases (ALAT) [13] [22].

In the context of this study series, the Rapid Diagnostic Test Determine ${ }^{\circledR} \mathrm{HBsAg}$ (Abbot, Tokyo, Japan) was used to research for HBsAg according to WHO guidelines [2] [30]. Determine ${ }^{\circledR} \mathrm{HBsAg}$ is an immunochromatographic test for the qualitative detection of hepatitis B surface antigen (HBsAg). The blood sample is deposited on the sample deposition area and migrates to the deposition area of 

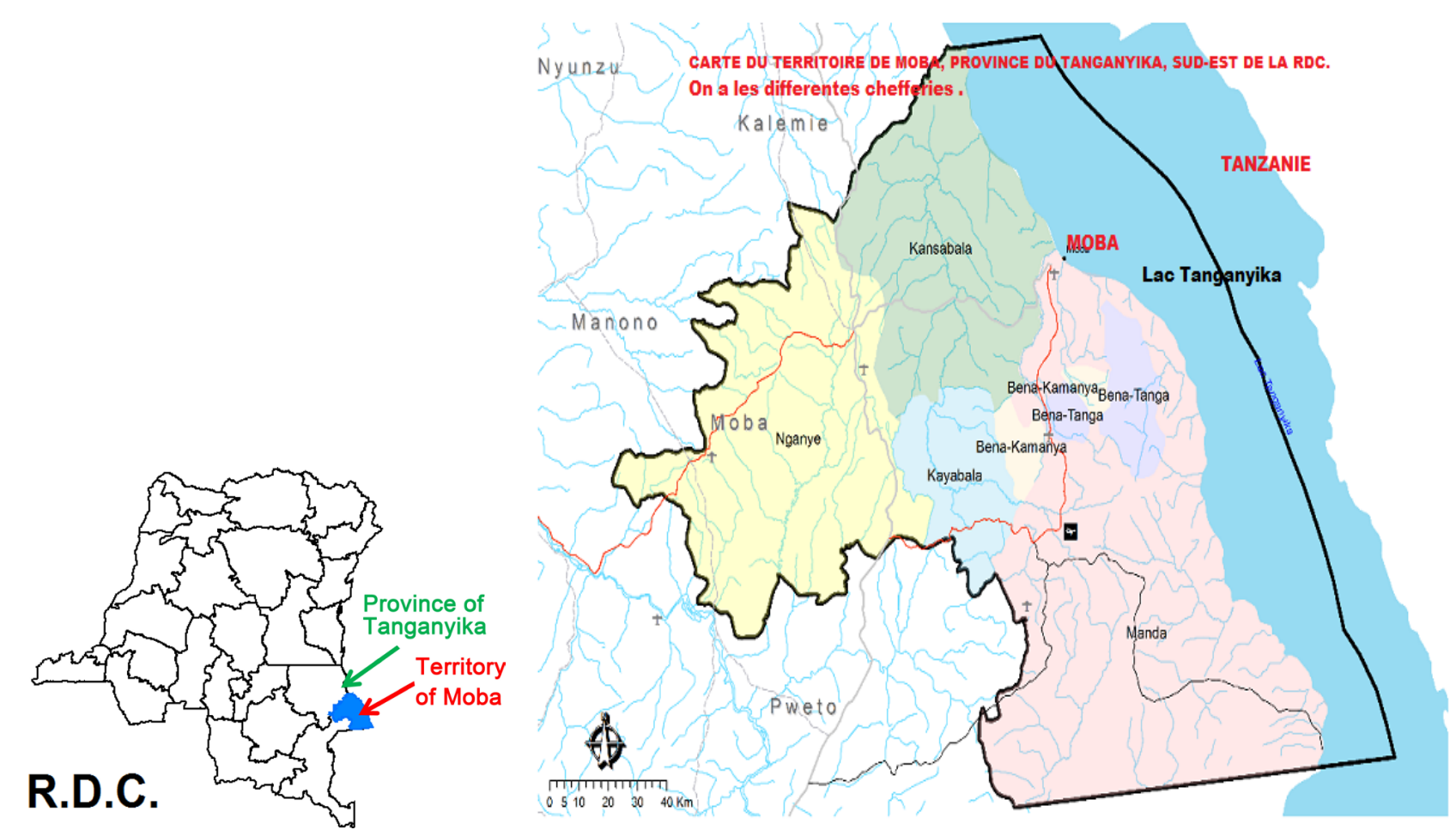

Figure 1. Geolocation and boundaries of the Moba territory. Moba is one of the five territories of the Tanganyika Province (Moba, Nyunzu, Kongolo, Manono and Kabalo). He is located in the South-East of Democratic Republic of Congo. Source: Map from www.caid.cd.

the conjugate; it is reconstituted and mixed with the selenium-antibody colloid conjugate Figure 1. This mixture continues to migrate on the solid phase to the immobilized antibodies at the patient window on the test. If HBsAg is present in the sample, it binds to the antibody of the selenium antibody-colloid conjugate and the patient window antibody by forming a red line. If, on the other hand, HBsAg is absent, the selenium antibody-colloid conjugate passes through the patient window without forming a red line. A procedure control bar is included in this assay system to ensure the validity of the assay [13] [29] [31]. The laboratory at the Katele HRC uses a single HVB (Determine ${ }^{\circledR}$ HBsAg) screening test without confirmation by more sensitive and specific tests such as Enzyme-Linked Immunosorbent Assay (ELISA).

\subsection{Data Processing and Analysis}

The data collected on a pre-established form were encoded on the Excel table (Microsoft, USA, 2010) before being exported for processing on the Epi Info 7.1 software (CDC, USA, 2012). The results were presented in the form of tables and figures showing observed numbers, frequencies, proportions and parameters of central tendency and dispersion (mean, standard deviation, median as necessary). The association between the variables studied was assessed using the unadjusted Pearson chi-square test. The allowed alpha error was $5 \%$ and any value of $p \leq 0.05$ was considered significant. 


\section{Results}

The results of this study concern the 1145 blood donors registered during the study period at the Katele Health Reference Center (Moba, DRC) laboratory. Of the 1145 blood donors examined, 926 (80.9\%) were between 18 and 38 years of age. The mean age was $30.6 \pm 6.9$ years with extremes ranging from 18 to 49 years (Table 1). Men were the most represented among blood donors followed by women with respectively 715 (62.5\%) and 430 (37.5\%). In terms of blood donor categories (types), family donors were the most commonly encountered: 953 (83.2\%), followed by paid donors $(\mathrm{n}=112$ or $9.8 \%)$ and irregular volunteers $(\mathrm{n}=$ 80 or $7.0 \%)$. The proportion of voluntary blood donations was lowest and only concerns circumstantial irregular voluntary donors (Table 1).

The study of the prevalence of viral hepatitis B (HBsAg) in our study series revealed a seroprevalence of 3.9\% ( $n=45)$ over three years (Figure 2). The year 2015 was the most contributory with $9.4 \%$ ( $n=42$ out of 448 registered blood donors). The years 2014 and 2016 had very low seroprevalence with respectively $0.3 \%$ (n $=1$ of 393 donors) and $0.7 \%$ ( $n=2$ of 304 blood donors). Throughout the study period, cases of $\mathrm{HBV}$ infection were only registered in the family donor category, i.e. $100 \%$. HBsAg seropositivity cases (HBsAg carriers) had an average age of 29.6 \pm 7.2 years and extremes of $19-42$ years. The seronegatives had an average age of $31.1 \pm 6.8$ years and the extremes of 18 to 49 years (Table 1 ).

Among the carriers of HBsAg, the female $(\mathrm{n}=19$ or $4.4 \%)$ and the 18 to 38 years age group were most significantly affected $(\mathrm{p}>0.05)$.

Family donors were significantly associated with hepatitis B infection ( $\mathrm{p}<$ 0.05). In our study series, age [OR 0.70 CI $95 \% 0.34-1.44$ ] and sex [OR $0.72 \mathrm{CI}$ 95\% 0.27 - 1.97] were not Associated with the occurrence of hepatitis B in blood donors $(\mathrm{p}>0.05)$ (Table 2).

Table 1. Characteristics of blood donors and seroprevalence of HBV.

\begin{tabular}{cccc}
\hline Characteristics & Total $\mathrm{n}(\%)$ & Seropositive $\mathrm{n}(\%)$ & Seronegative $\mathrm{n}(\%)$ \\
\hline Age (years) & & & \\
$18-38$ & $926(80.9)$ & $39(3.4)$ & $887(77.5)$ \\
$39-58$ & $219(19.1)$ & $6(0.5)$ & $203(18.6)$ \\
Means & 30.6 & 29.6 & 31.1 \\
Sd & 6.9 & 7.2 & 6.8 \\
Mediane & 30.5 & 29 & 30 \\
Extremes & $18-49$ & $19-42$ & $18-49$ \\
Sex & & & $689(60.2)$ \\
Male & $715(62.5)$ & $26(2.3)$ & $411(35.9)$ \\
Female & $430(37.5)$ & $19(1.7)$ & $908(79.3)$ \\
Types of donors & & & $80(7.0)$ \\
FD & $953(83.2)$ & $45(3.9)$ & $112(9.8)$ \\
VD (=CIVD) & $80(7.0)$ & 0 & 0 \\
PD & $112(9.8)$ & & \\
\hline
\end{tabular}

Sd: Standard Deviation; FD: Family Donors; PD: Paid Donors; VD: Volunteer Donors (=Circumstantial irregular volunteer donors); CIVD: Circumstantial Irregular Volunteer Donors. 


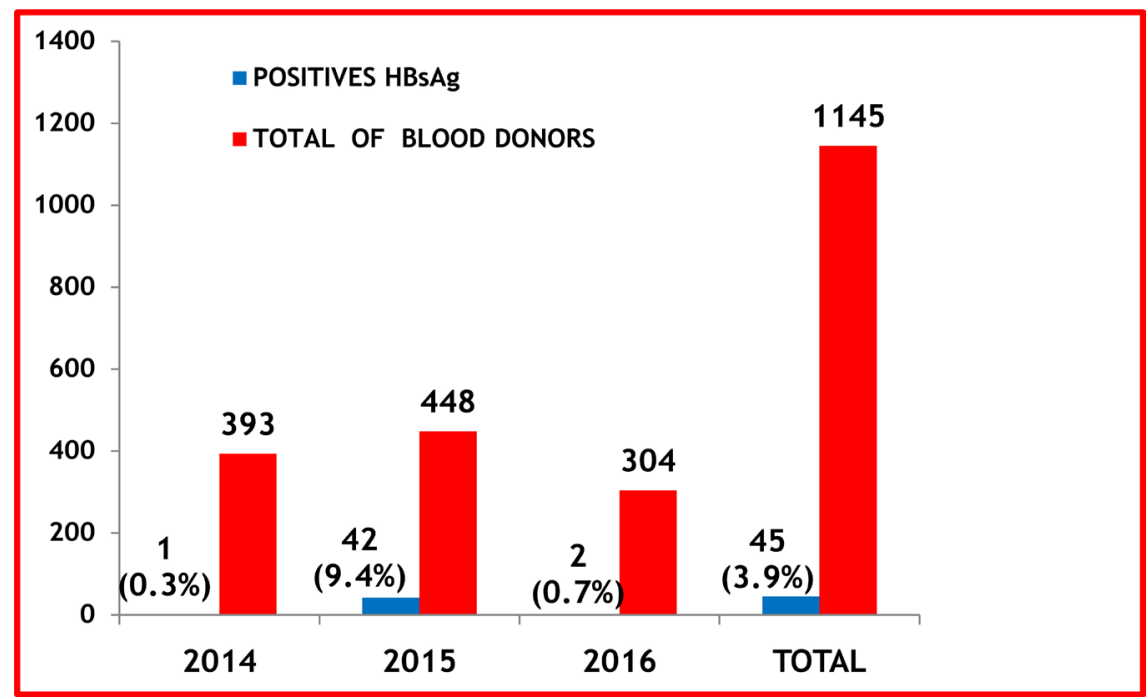

Figure 2. Evolution of the prevalence of HBV infection from 2014 to 2016.

Table 2. Characteristic analysis and seroprevalence of HBV (HBsAg) in blood donors.

\begin{tabular}{|c|c|c|c|c|c|}
\hline \multirow{2}{*}{ Variables } & \multirow{2}{*}{$\begin{array}{l}\text { Total } \\
\mathrm{n}(\%)\end{array}$} & \multicolumn{4}{|c|}{ HBV (AgHBS) to the blood donors } \\
\hline & & $\begin{array}{l}\text { Seropositive } \\
\text { n (\%) }\end{array}$ & $\begin{array}{c}\text { Seronegative } \\
\mathrm{n}(\%)\end{array}$ & OR (CI 95\%) & $\mathrm{p}$-value \\
\hline \multicolumn{6}{|l|}{ Age (years) } \\
\hline $18-38$ & $926(100)$ & $39(4.2)$ & $887(95.8)$ & & \multirow{2}{*}{0.338} \\
\hline $39-58$ & $219(100)$ & $6(2.7)$ & $213(97.3)$ & {$[0.34-1.44]$} & \\
\hline \multicolumn{6}{|l|}{ Sex } \\
\hline Male & $715(100)$ & $26(3.6)$ & $689(96.4)$ & \multirow{2}{*}{$\begin{array}{c}0.72 \\
{[0.27-1.97]}\end{array}$} & \multirow[b]{2}{*}{0.341} \\
\hline Female & $430(100)$ & $19(4.4)$ & $411(95.6)$ & & \\
\hline \multicolumn{6}{|l|}{ Types of donors } \\
\hline FD & $953(100)$ & $45(4.7)$ & $908(95.3)$ & & \multirow{3}{*}{0.032} \\
\hline VD (=CIVD) & $80(100)$ & - & $80(100)$ & & \\
\hline $\mathrm{PD}$ & $112(100)$ & - & $112(100)$ & - & \\
\hline
\end{tabular}

OR: Odd Ratio; IC Confidence Interval; Sd: Standard Deviation; FD: Family Donors; PD: Paid Donors; VD: Volunteer Donors (=Circumstantial Irregular Volunteer Donors); CIVD: Circumstantial Irregular Volunteer Donors.

\section{Discussion}

\subsection{Characteristics of Blood Donors}

During the period of our study on the prevalence of HBV infection in blood donors, blood donors were found to be young adults aged 18 to 49 years and an average of $30.6 \pm 6.9$ years. This age corresponds or is close to what some authors [2] [20] [24] [25] [32] [33] [34] [35] [36] had encountered in different countries. At this age of intense physical activity, individuals consider themselves strong and able to give blood as old men, already weakened by the weight of the age. Male individuals were the most registered among blood donors (62.5\%). This 
observation has been preferentially evoked in several studies [1] [5] [14] [20] [22] [24] [25] [28] [37] [38]. For Batina et al. [26], blood donors were mainly women. The arguments favoring male predominance take into account the cultural habits and certain physiological predispositions of women to be excluded from the category of blood donors. Indeed, on the one hand to give blood, the donor must feel stronger and fit for that responsibility. In Africa, it is the man who is considered to be the strongest and responsible for any situation that threatens the family: therefore it is better able to give blood than the woman. On the other hand, pregnancy and breastfeeding are contraindications to blood donation, which would reduce women's chances of donating blood. Some authors also mention menstrual blood loss in women [5] [6]. Blood donors were predominantly family donors (83.2\%) [5] [25]. This study demonstrates the persistence of paid and family donors in our environment. These categories of donors have been associated for years and in several regions of the world with the risk of transmission of infectious agents during blood transfusions [12] [15] [24] [25] [26] [28] [32] [33] [38] [39] [40] [41] [42]. We believe that the trust of family members in family blood donation and the poor public mobilization policy in favor of regular blood donations are the basis of this situation [8]. Health authorities and partners involved in blood safety and management should be involved to resolve this situation as in some parts of the world and the Democratic Republic of Congo [27] [28] [33] [43]. Our safety of the blood recipient must not remain only in the embryonic stage dating back to 2001 (rehabilitation and inauguration of the National Center for Blood Transfusion) [44]. Several awareness campaigns and funding of national blood transfusion program (NBTP) activities for voluntary and regular blood donations are therefore necessary.

\subsection{The Seroprevalence of HBV Infection in Blood Donors}

In Africa, the prevalence of HBV infection is $0.2 \%$ to $20 \%$ among blood donors [5] [10]. The cumulative seroprevalence of HBV infection ( $\mathrm{HBsAg}$ ) during the three years of study was 3.9\%. It is close to the results encountered by Kabinda [33] 4.2\% and Namululi [27] 3.7\% in the DRC, and Rakotoniaina [14] in Madagascar with $3.21 \%$.

This prevalence of HBV among blood donors is lower than in some studies: $20 \%$ in Tanzania [16], $14.96 \%$ in Burkina Faso [45], 14.0\% in Nigeria [17], 4.7\% in Ethiopia [20] and 8.8 in Uganda [21]. However, it is higher than India's 1.1\% [1], in Nepal 1.2\% [22], in Canada $0.007 \%$ to $0.06 \%$ [46], in Iran 0.15\% [47], China $1.085 \%$ [48], Italy 0.007 [49] and Rwanda $2.8 \%$ [21].

In the Democratic Republic of Congo, this seroprevalence is lower than Kakisingi [25] 8.01\% and Michel [6] 6.8\% in Lubumbashi, Batina in Kisangani 6.0\% [7], Mbendi in Kinshasa 9.2\% [24]; greater than 1.6\% obtained by Kabamba Nzaji [28] in rural Kamina; and close to 3.7\% of Namululi [27] and Kabinda [33] $4.2 \%$ of volunteer donors in Bukavu. Infectious risk in blood recipients appears to be certain in all provinces of the DRC and viral hepatitis B continues to be the reason for exclusion from donating blood. This risk is more acute in developing 
countries than in developed countries [47]. The difference between countries and certain environments relative to others is related to socioeconomic status, the level of education of the population, the organization of the health system, the vaccination status of the population and the quality of selection Of candidates for blood donation [47] [50].

The time-series trend in the evolution of the seroprevalence of HBV infection in our study does not make it possible to give a serious and accurate judgment on the evolution of HBV infection in our environment. The peak was observed in 2015 with $9.4 \%$ while $0.3 \%$ in 2014 and $0.7 \%$ in 2106 . It would be necessary to wait for the evolution of this seroprevalence in the following years to make the judgment. However, we believe that on the whole, this fluctuating behavior would be influenced by family donors known as donors at risk of transfusion-transmitted infection (TTIs) [32] [40] [41] [51].

In our study, the observed seroprevalence of HBV infection in females (4.4\%) was higher than that of males (3.6\%). The difference observed is not statistically significant $(p>0.05)$. This was mentioned by Michel [6] in the DRC. Similarly, the prevalence of HBSAg in blood donors aged 18 to $38(4.2 \%)$ and 39 to 58 years $(2.7 \%)$ was not statistically significant $(\mathrm{p}>0.05)$. Unlike Xie [10], for who age was associated with the high seroprevalence of HBV infection in Equatorial Guinea. On the other hand, the blood donation category is associated with HBV infection.

Family donors were the only ones affected by HBV in our series and the difference observed was significant $(p<0.05)$ [6]. It is here that the need for NBTP to organize public awareness campaigns in favor of regular voluntary blood donations in order to achieve the WHO 2020 targets: 100\% voluntary donations [52].

For this study, age and sex are not statistically associated with the occurrence of Hepatitis B infection. Michel [6] and Batina [7] fund the significative association between age and the AgHBSAg in Lubumbashi and Kisangani (DRC). The rural environment has been identified as associated with the risk of transmission of hepatitis B by Kabinda [33], which requires the strengthening of epidemiological surveillance measures for blood donors.

\subsection{From the Method of Screening and Diagnosis of HBV Infection: Qualitative Assay of HBsAg}

Apart from the risk of contamination of the blood recipient during the transfusion discussed in this work, it is useful to highlight the limits of our strategy of securing blood donations. Indeed, in addition to the fact that the NBTP recommends the use of a single rapid diagnostic test (RDT) to assess the risk of HBV infection, Determine HBsAg tests are recognized to be less sensitive in some studies [53] [54] [55]. The ELISA chain can be considered as an alternative for confirmation of the results [25] [26] [34]. In Madagascar, in the CHUA-JRA Ampefiloha Immunology laboratory, the results obtained during the evaluation of the rapid tests for the detection of HBsAg showed a sensitivity of $96.1 \%$, a specificity 
of 93.2\%, 93.6\% PPV (positive predictive value), 95.8\% NPV (negative predictive value) for the Determine $\mathrm{HBsAg}^{\circledR} \mathrm{Kit}$, whereas optimal diagnostic criteria require sensitivity and specificity greater than $98 \%$ [55].

A study conducted in India [56] between 2004 and 2005 revealed that 1027 cases of hepatitis B surface negative antigen were positive in $18 \%$ antibody to HBV antibodies and $21 \%$ with DNA-HVB. In our study series, no serological results were confirmed, which may limit the scope of our work.

Determine $\mathrm{HBsAg}^{\circledR}$ is a qualitative, in vitro, visual-quality immunoassay for the detection of hepatitis B surface antigen (HBsAg) in human serum, plasma or whole blood [13] [57] [58]. No test can absolutely guarantee that a sample does not contain low concentrations of $\mathrm{HBsAg}$, such as those presented at a very early stage of infection. Therefore, a negative result does not exclude the possibility of exposure to HBsAg or infection with HBsAg [31] [34] [57] [58].

In order to increase our ability to diagnose and distinguish acute HBV infection from chronic infection in endemic Congolese we recommend: (1) That the NBTP uses two RDTs to diagnose HBsAg (instead of a single test currently performed): we are a low-income country and the cost of HBsAg research by RDTs would be affordable for all Structures; (2) Long-term use of ELISA [23] [34]. In the absence of ELISA, detection of HBsAg may be associated with the patient's symptoms and other hepatitis B viral serum markers such as anti-HBc, anti-HBc and viral DNA ( There are low cost automata) depending on whether or not they have been vaccinated [24] [57] [59]. Deoxyribonucleic acid (DNA) from HBV can be detected two to three weeks prior to the detection of HBsAg [60]. For Blanco et al. [61] in Argentina, the nucleic acid test contributes greatly in reducing the potential infectious risks of transmission of hepatitis $B$ virus.

Anti-HBc is the first antibody to appear in serum following exposure to $\mathrm{HBV}$, less than one month after the onset of HBsAg. It is not recommended for the detection of hepatitis B but is a useful marker in the context of acute hepatitis B diagnosis in endemic areas [24] [59]. In Malaysia, one thousand HBsAg negative subjects were found to be $87.3 \%$ positive for Anti-HBc by ELISA [43]. However in our context, no paraclinic examination is very necessary than the better selection of blood donor candidates (pre-test counseling).

Securing blood donations is a responsibility of the government [50] and its partners who should make better supplies of good quality blood to the Congolese population. This includes regular voluntary donations, good quality pre-test counseling, more effective screening and diagnostic tests, training of blood transfusion personnel and the availability of sufficient blood banks and epidemiological follow-up Seroprevalence in both urban and rural areas.

\section{Conclusion}

The results of our study demonstrate the need for epidemiological monitoring of blood donations and the strengthening of transfusion safety measures. The overall seroprevalence of HBsAg of 3.9\% over three years was influenced by the highest peak observed in 2015 (9.4\%), while prevalences of $0.3 \%$ and $0.7 \%$ were observed 
in 2014 and 2016. The instability of the seroprevalence of hepatitis B virus infection among blood donors and family donors is insufficient to ensure healthy blood donation among recipients in our environment. Apart from the negative impact of family blood donations, we should highlight the limitations of TDR (Determine ${ }^{\circledR} \mathrm{HBsAg}$ ) used in our context with respect to HBV sensitivity and specificity. The NBTP should incorporate more efficient tests into its strategy and, if necessary, a second diagnostic confirmation test. Safekeeping of the recipient should not remain in the embryonic stage dating back to 2001 (rehabilitation and inauguration of the National Blood Transfusion Center). The new strategies should be adapted according to field research data.

\section{Acknowledgements}

The authors would like to thank MAKA BONFOLO Félix, Jacques NSOMWE AB$\mathrm{EDI}^{\dagger}$, Marie KISEME ${ }^{\dagger}$ and the medical laboratory team of the Katele Health Reference Center in Moba-Port (Jérôme KAHENGA KIBAMBE and Saleh MWEMEDI) for their help in data collects.

\section{Conflict of Interest}

The authors do not declare any conflicts of interest in connection with this study.

\section{References}

[1] Giri Purushottam, A., Deshande Jayant, D., Phalke Deepak, B. and Karle Laximan, B. (2012) Seroprevalence of Transfusion Transmissible Infections among Voluntary Blood Donors at a Tertiary Care Teaching Hospital in Rural Area of India. Journal of Family Medicine and Primary Care, 1, 48-51. https://doi.org/10.4103/2249-4863.94452

[2] OMS (2016) Hepatitis B. Fact Sheet No. 204. www.who.int/mediacentre/factsheets/fs204 www.who.int/mediacentre/factsheets/fs204/fr

[3] Zhang, L., Jiao, S., Yang, Z., Xu, L., Liu, L., Feng, O., et al. (2016) Prevalence of Hepatitis E Virus Infections among Blood Donors in Mainland China: A Meta-Analysis. Transfusion, 57, 248-257. https://doi.org/10.1111/trf.13937

[4] Pozzeto, B. and Garraud, O. (2016) New Viral Risks in Blood Transfusion by 2016 [Nouveaux risques viraux en transfusion sanguine à l'horizon 2016]. Transfusion Clinique et Biologique, 23, 20-27. https://doi.org/10.1016/j.tracli.2015.12.004

[5] Kiire, C.F. (1996) The Epidemiology and Prophylaxis of Hepatitis B in Sub-Saharan Africa: A View from Tropical and Subtropical Africa. Gut, 38, S5-S12. https://doi.org/10.1136/gut.38.suppl_2.s5

[6] Michel, K.N., Pascal, K.M., Mariette, K.K., Blaise, I.K., Tonny, N.N., Ignace, B.K., et al. (2016) Seroprevalence Hepatitis B in Blood Donors at Lubumbashi, DR Congo (Case of Provincial Hospital Sendwe Reference). Open Access Library Journal, 3, e3105. https://doi.org/10.4236/oalib.1103105

[7] Batina Agasa, B., Gulbis, M., Dramaix, W. and Losimba Likwela, L. (2013) Evolution of Markers of Viral Infections Transmitted by Transfusion from 2005 to 2008 in Kisangani. Democratic Republic of Congo [Évolution des marqueurs d'infections 
virales transmises par transfusion de 2005 à 2008 à Kisangani. République Démocratique du Congo]. Revue Médicale des Grands Lacs, 2, 283-292.

[8] Diro, E., Alemu, S. and Gy, A. (2008) Blood Safety and Prevalence of Transfussion Transmissible Viral Infections among Donors at the Red Cross Blood Bank in Gondar University Hospital. Ethiopian Medical Journal, 46, 7-13.

[9] World Health Organization. Global Database on Blood Safety: Report 2001-2002. http://www.who.int/bloodsafety/GDBS_Report_2001-2002.pdf

[10] Xie, D.-D., Li, J., Chen, J.-T., Eyi, U.M., Matesa, R.A., Obono, M.M.O., et al. (2015) Seroprevalence of Human Immunodeficiency Virus, Hepatitis B Virus, Hepatitis C Virus, and Treponema pallidum Infections among Blood Donors on Bioko Island, Equatorial Guinea. PLoS ONE, 10, e0139947. https://doi.org/10.1371/journal.pone.0139947

[11] Kabemba Bukasa, H., Kamuanya Wa Tshitanda, E., Kitengie Tshite, J., Atibu Bin Atibu, B., Ngiele Mposhi, D. and Pungue Kabiswe, J. (2017) Seroprevalence of Human Immunodeficiency Virus and Hepatitis B and C Infections in Blood Donors in the Security Transfusion Service Center of Kalemie (Democratic Republic of Congo) [Séroprévalence des infections par les virus de l'immunodéficience humaine et des hépatites $\mathrm{B}$ et $\mathrm{C}$ chez les donneurs de sang au service de sécurité transfusionnelle de Kalemie (République Démocratique du Congo)]. Médecine d'Afrique noire, 64, 47-56.

[12] Belyhun, Y., Maier, M., Mulu, A., Diro, E. and Liebert Uwe, G. (2016) Hepatitis Virus in Ethiopia: A Systematic Review and Meta-Analysis. BMC Infectious, 16, 761 https://doi.org/10.1186/s12879-016-2090-1

[13] Hamdoun Zahmoul, M. and Bahri, O. (2010) Assay of AgHBS: New Marker for the Monitoring of Chronic Viral Hepatitis B [Dosage de l'AgHBS: nouveau marqueur pour le suivi des Hépatites virales chroniques B]. Rev. Tunisienne d Infectiologie, 4, 117-121.

[14] Rakotoniaina, A.I., Randriamanantany, Z.A., Ranaivosoa, K.H.M., Andriambelo, V., Fortune, H., Rakoto Alson, O.A., et al. (2013) Seroprevalence of HIV, HBV, HCV and Treponema pallidum in Voluntary Blood Donors at the National Blood Transfusion Center in Antananarivo from 1992 to 2010 [Séroprévalence du VIH, VHB, VHC et de Treponema pallidum chez les donneurs du sang bénévoles au centre national de transfusion sanguine d'Antananarivo de 1992 à 2010]. Revue Medicale de Madagascar, 3, 264-268.

[15] Hwang, E.W. and Cheung, R. (2011) Global Epidemiology of Hepatitis B Virus (HBV) Infection. North American Journal of Medical Sciences, 4, 7-13. https://doi.org/10.7156/v4i1p007

[16] Matee, M.I., Lyamuya, E.F., Mbena, E.C., Magessa, P.M., Sufi, J., Marwa, G.J., et al. (1999) Prevalence of Transfusion-Associated Viral Infectious and Syphilis among Blood Donors in Muhimbili Medical Centre, Dar es Salaam, Tanzania. East African Medical Journal, 76, 167-171.

[17] Musa, B.M., Bussell, S., Borodo, M.M., Samaila, A.A. and Femi, O.L. (2015) Prevalence of Hepatitis B Virus Infection in Nigeria, 2000-2013: A Systematic Review and Meta-Analysis. Nigerian Journal of Clinical Practice, 18, 2, 163-172. https://doi.org/10.4103/1119-3077.151035

[18] Nwankwo, E., Momodu, I., Umar, I., Musa, B. and Adeleke, S. (2012) Seroprevalence of Major Blood-Borne Infections among Blood Donors in Kano, Nigeria. Turkish Journal of Medical Sciences, 42, 337-341.

[19] Noah Noah, D., Njouom, R., Bonny, A., Pirsou, Meli, J. and Sida Biwole, M. (2011) HBs Antigen Prevalence in Blood Donors and the Risk of Transfusion of Hepatitis 
$\mathrm{B}$ at the Central Hospital of Yaounde, Cameroon. Open Journal of Gastroenterolo$g y, 1,23-27$. https://doi.org/10.4236/ojgas.2011.12004

[20] Tessema, B., Yismaw, G., Kassu, A., Amsalu, A., Mulu, A., Emmrich, F. and Sack, U. (2010) Seroprevalence of HIV, HBV, HCV and Syphilis Infections among Blood Donors at Gondar University Teaching Hospital, Northwest Ethiopia: Declining Trends over a Period of Five Years. BMC Infectious Diseases, 10, 111. www.biomedcentral.com/1471-2334/10/111 https://doi.org/10.1186/1471-2334-10-111

[21] Tagny, C.T., Owusu-Ofori, S., Mbanya, D. and Deneys, V. (2010) The Blood Donor in Sub-Saharan Africa: A Review. Transfusion Medicine, 20, 1-10. https://doi.org/10.1111/j.1365-3148.2009.00958.x

[22] Tiwari, B.R., Ghimire, P., Kanoul, S.R. and Rajkarnikar, M. (2010) Seroprevalence of HBV and HCV in Blood Donors: A Study from regional Blood Transfusion Services of Nepal. Asian Journal of Transfusion Science, 4, 91-93. https://doi.org/10.4103/0973-6247.67026

[23] Mavenyengwa, R.T., Munyaradzi, M., Chipare, I. and Shoombe, E. (2014) Prevalence of Human Immunodeficiency Virus, Syphilis, Hepatitis B and C in Blood Donations in Namibia. BMC Public Health, 14, 424.

https://doi.org/10.1186/1471-2458-14-424

[24] Mbendi Nlombi, C., Longo-Mbenza, B., Mbendi Nsukini, S., Muyembe Tamfumu, J.J., Situa Kibanza, H. and Vangu Ngoma, D. (2001) Prevalence of HIV and HBS Antigen in Blood Donors, Residual Risk of Contamination in Recipients of Blood of East Kinshasa, Democratic Republic of Congo [Prévalence du VIH et de l'Antigène HBS chez les donneurs du sang, risque résiduel de contamination chez les receveurs du sang de Kinshasa-Est, République Démocratique du Congo]. Medecine Tropicale, 61, 139-1423.

[25] Kakisingi Ngama, C., Mukuku, O., Matanda Kapend, S., Manika Muteya, M., Kyabu Kabila, V., Kasamba Ilunga, E., et al. (2016) Epidemiological Profile and Seroprevalence of Blood Donors at University Clinics in Lubumbashi, Democratic Republic of Congo [Profil épidémiologique et séroprévalence des donneurs de sang aux cliniques universitaires de Lubumbashi, République Démocratique du Congo]. Pan African Medical Journal, 23, 175.

http://www.panafrican-med-journal.com/content/article/23/175/full/

[26] Batina, A., Kabemba, S. and Malengela, R. (2007) Infectious Markers in Blood Donors in the Democratic Republic of Congo (DRC) [Marqueurs infectieux chez les donneurs de sang en République Démocratique du Congo (RDC)]. Revue Médicale de Bruxelles, 28, 145-149.

[27] Namululi, B.A., Guerrieri, C. and Dramaix, M. (2012) Impact of Blood Donor Recruitment on HIV and HBV Prevalence in Bukavu, Democratic Republic of Congo [Impact du mode de recrutement des donneurs de sang sur la prévalence du VIH et du VHB à Bukavu, République Démocratique du Congo]. Médecine et Santé Tropicales, 22, 69-74.

[28] Kabamba Nzaji, M. and Kabyla Ilunga, B. (2013) Prevalence of Infectious Markers in Rural Blood Donors. Case of the General Hospital of Reference of Kamina [Prévalence des marqueurs infectieux chez les donneurs de sang en milieu rural. Cas de l'Hôpital General de Reference de Kamina]. Santé Publique, 25, 213-217.

[29] Jaroszewicz, J., Serrano, B.C., Wursthorn, K., Deterding, K., Schlue, S., Raupach, R., et al. (2010) Hepatitis B Surface Antigen (HBsAg) Levels in the Natural History of Hepatitis B Virus (HBV) Infection: A European Perspective. Journal of Hepatology, 52, 514-522. https://doi.org/10.1016/j.jhep.2010.01.014 
[30] World Health Organization (1975) Resolution WHA28.72: Use and Production of Human Blood and Its Derivatives. 28th World Health Assembly, Geneva, 13-30 May 1975. [L'Assembléemondiale de la Santé (1975) Résolution WHA28.72: Utilisation et obtention du sang humain et de ses dérivés. Vingt-Huitième Assemblée mondiale de la Santé, Genève, 13-30 Mai 1975, Genève].

[31] Determine HBSAg, Mars (2007) Inverness Medical Japan. www.determinetest.com

[32] Benjemiar, R. and Gouider, E. (2014) Seroprevalency of Transmission-Transmitted Infection in First-Time Volunteer and Replacement Donors in Tunisia. Transfusion Clinique et Biologique, 21, 303-308. https://doi.org/10.1016/j.tracli.2014.10.001

[33] Kabinda, J.M., Miyanga, S.A., Misingi, P. and Ramarani, S.Y. (2014) Hepatitis B and $\mathrm{C}$ in Unpaid Blood Donors in Eastern Democratic Republic of Congo [Les hépatites $\mathrm{B}$ et $\mathrm{C}$ chez les donneurs bénévoles de sang et non rémunérés à l'Est de la République Démocratique du Congo]. Transfusion Clinique et Biologique, 21, 111115. https://doi.org/10.1016/j.tracli.2014.04.001

[34] Kra, O., N’Dri, N., Ehui, E., Ouattara, B. and Bissagnene, E. (2007) Prevalence of HBS Antigen in Blood Donors and the Regional Blood Transfusion Center in Bouaké, Ivoire-coast, 2001 [Prévalence de l'Antigène HBS chez les donneurs de sang et au centre régional de transfusion sanguine de Bouaké Côte d'Ivoire en 2001]. Bulletin de la Société de Pathologie Exotique, 100, 127-129.

[35] Portelinha Filho, A.M., Ulloffo, D.O., Naseimento, C., Nicastro Tannouri, T., Troiani, C., Lopes Ascencio, E., Bonfim, R., et al. (2009) Seroprevalence of HBV, HCV and HIV Co-Infection in Selected Individual from State of Sao Paulo, Brazil. Memórias do Instituto Oswaldo Cruz, 104, 960-963. https://doi.org/10.1590/S0074-02762009000700003

[36] Ehoussou, K., Tiembre, I., Benie, J., N’Doutable, M., Dagnan, S., Djeha, D., et al. (1997) Evaluation of Seroprevalence of HIV and HBV Infection among Military Blood Donors in Abidjan [Evaluation de la séroprévalence de l'infection à VIH et VHB chez les donneurs de sang militaires à Abidjan]. Médecine d'Afrique noire, 44, 620-624.

[37] Shrestha, A.C., Ghimire, P., Tiwari, B.R. and Rajkarnikar, M. (2009) TransfusionTransmissible Infectious among Blood Donors in Kothmandu, Nepal. Journal of Infection in Developing Countries, 3, 794-797.

[38] Dray, X., Dray-Spira, R., Bronstein, J.A. and Mattera, D. (2005) Seroprevalence of Human Immunodeficiency Viruses and Hepatitis B and C among Blood Donors in the Republic of Djibouti [Séroprévalence des virus de l'immunodéficience humaine et des hépatites $\mathrm{B}$ et $\mathrm{C}$ parmi les donneurs de sang en République de Djibouti]. Medecine Tropicale, 65, 39-42.

[39] WHO (2015) Transfusion Safety and Blood Supply, Fact Sheet No. 279 [OMS. Sécurité transfusionnelle et approvisionnement en sang, Aide-mémoire No. 279].

[40] Pillonel, J., Saura, C. and Courouce, A.M. (1998) Prevalence of HIV, HTLV and Hepatitis B and C Viruses in Blood Donors in France [Prévalence du VIH, de l' HTLV et des virus des hépatites B et C chez les donneurs de sang en France]. 1992-1996. Transfusion Clinique et Biologique, 5, 305-312. https://doi.org/10.1016/S1246-7820(98)85001-5

[41] Diarra, A., Kouriba, B., Baby, M., Murphy, E. and Lefrere, J.-J. (2009) HIV, HCV, HBV and Syphilis Rate of Positive Donations among Blood Donations in Mali: Lower Rates among Volunteer Blood Donors. Transfusion Clinique et Biologique, 16, 444-447. https://doi.org/10.1016/j.tracli.2009.09.004

[42] Noubiap, J.J., Joko, W.Y., Nansseu, J.R., Tene, U.G. and Siaka, C. (2013) Sero-Epidemiology of Human Immunodeficiency Virus, Hepatitis B and C Viruses, and Sy- 
philis Infections among First-Time Blood Donors in Edéa, Cameroon. International Journal of Infectious Diseases, 17, 832-837. https://doi.org/10.1016/j.ijid.2012.12.007

[43] Hudu, S.A., Harmal, N.S., Saeed, M.I., Alshari, A.S., Malik, Y.A., Niazlin, M.T., et al. (2016) Molecular and Serological Detection of Occult Hepatitis B Virus among Healthy Hepatitis B Surface Antigen-Negative Blood Donors in Malaysia. African Health Sciences, 16, 677-683. https://doi.org/10.4314/ahs.v16i3.6

[44] Kabinda Maotela, J., Ramazani, S.Y., Misingi, P. and Dramaix-Wilme, M. (2015) Blood Transfusion in the Democratic Republic of Congo: Efforts and Challenges [Transfusion sanguine en République Démocratique du Congo: Efforts réalisés et défis à relever]. Médecine et Santé Tropicale, 25, 342-349.

[45] Mecky, I.N.M., Pius, M.M. and Eligius, F.L. (2006) Seroprevalence of Human Immunodeficiency Virus, Hepatitis B and C Viruses and Syphilis Infections among Blood Donors at the Muhimbili National Hospital in Dar Es Salaam, Tanzania. BMC Public Health, 6, 21. http://www.biomedcentral.com/1471-2458/6/21 https://doi.org/10.1186/1471-2458-6-21

[46] O’Brien, S.F., Xi, G., Fan, W., Yi, Q.L., Fearon, M.A., Scalia, V., et al. (2008) Epidemiology of Hepatitis B in Canadian Blood Donors. Transfusion, 48, 2323-2330. https://doi.org/10.1111/j.1537-2995.2008.01845.x

[47] Farshadpour, F., Taherkhani, R., Tajbakhsh, S., Gholizadeh Tangestani, M., Hajiani, G., Sharifi, N., et al. (2016) Prevalence and Trends of Transfusion-Transmissible Viral Infections among Blood Donors in South of Iran: An Eleven-Year Retrospective Study. PLoS ONE, 11, e0157615. https://doi.org/10.1371/journal.pone.0157615

[48] Liu, G.-C., Sui, G.-Y., Liu, G.-Y., Zheng, Y., Deng, Y., Gao, Y.-Y., et al. (2013) A Bayesian Meta-Analysis on Prevalence of Hepatitis B Virus Infection among Chinese Volunteer Blood Donors. PLoS ONE, 8, e79203. https://doi.org/10.1371/journal.pone.0079203

[49] Gonzalez, M., Regine, V., Piccinini, V., Vulcano, F., Giampaolo, A. and Hassan, H.J. (2005) Residual Risk of Transfusion Transmitted Human Immunodeficiency Virus, Hepatitis C Virus, and Hepatitis B Virus Infections in Italy. Transfusion, 45, 1670 1675. https://doi.org/10.1111/j.1537-2995.2005.00576.x

[50] WHO (2010) Screening for Transmitted Diseases in Blood Transfusion: Recommendations [OMS, Dépistage des infections transmissibles par transfusion dans les dons de sang: Recommandations]. NLM-WB 356, Organisation mondiale de la Santé, 2-24.

[51] Tafesse, T.B., Geru, A.A., Gobalee, S., Belly, G.D., Belew, M.T., Arso, D., et al. (2016) Seroprevalence and Diagnosis of HIV, HBV, HCV and Syphilis Infections among Blood Donors. Human Antibodies, 16, 1-17.

[52] WHO and IFRC (2011) Towards 100\% Voluntary Blood Donation, Global Framework for Action [OMS et FICR. Vers $100 \%$ de dons de sang volontaire, Cadre mondial d'action]. NLH-WH 460, 6-25.

[53] Njai, H.F., Shimakawa, Y., Sanneh, B., Ferguson, L., Ndow, G., Mendy, M., et al. (2015) Validation of Rapid Point-of-Care (POC) Tests for Detection of Hepatitis B Surface Antigen in Field and Laboratory Settings in the Gambia, Western Africa. Journal of Clinical Microbiology, 53, 1156-1163. https://doi.org/10.1128/JCM.02980-14

[54] Shivkumar, S., Peeling, R., Jafari, Y., Joseph, L. and Pai, N.P. (2012) Rapid Point-ofCare First-Line Screening Tests for Hepatitis B Infection: A Metaanalysis of Diagnostic Accuracy (1980-2010). American Journal of Gastroenterology, 107, 1306-1313. https://doi.org/10.1038/ajg.2012.141 
[55] Rajaonatahina, D.H., Randriamanantany, Z.A., Rakotomalala, R., Andriamahenina, R., Contamin, B., Alson, R., et al. (2011) Evaluation of Rapid Tests for the Detection of HBsAg in the Immunology Laboratory CHUA-JRA Ampefiloha, Antananarivo, Mada-gascar [Evaluation des tests rapides pour le dépistage de l'AgHBs au laboratoire d'Immunologie CHUA-JRA Ampefiloha, Antananarivo, Madagascar]. Revue Medicale de Madagascar, 1, 20-23.

[56] Bhattacharya, P., Chandra, P.K., Dattas, S., Banerjee, A., Chakraborty, S., Rajendran, K., et al. (2007) Significant Increase in HBV, HCV, HIV and Syphilis Infectious among Bloods Donors in West Bengal, Eastern Indian 2004-2005: Exploratory Screening Reveals High Frequency of Occult HBV Infection. World Journal of Gastroenterology, 13, 3730-3733. https://doi.org/10.3748/wjg.v13.i27.3730

[57] Poveda, J.-D. (2008) Screening and Biological Monitoring, Contributions of Molecular Biology Techniques [Hépatites Virales B: Dépistage et suivi biologique, Apports des techniques de biologie moléculaire]. Laboratoire Pasteur Cerba, Tunis.

[58] World Health Organization (WHO) (2004) Laboratory Biosafety Manual. 3rd Edition, World Health Organization, Geneva.

[59] National Institute of Public Health of Quebec (2016) Recommended Laboratory Tests for Screening for Hepatitis B Virus, Government of Québec [Institut national de santé publique du Québec (2016) Analyses de laboratoire recommandées pour le dépistage de l'infection par le virus de l'hépatite B, Gouvernement du Québec]. http://www.inspq.qc.ca

[60] Assal, A., Barlet, V., Deschaseaux, M., Dupont, I., Gallian, P., Guitton, C., et al. (2009) Sensitivity of Two Hepatitis B Virus, Hepatitis C Virus (HCV), and Human Immunodeficiency Virus (HIV) Nucleic Acid Test Systems Relative to Hepatitis B Surface Antigen, Anti-HCV, Anti-HIV, and p24/Anti-HIV Combination Assays in Seroconversion Panels. Transfusion, 49, 301-310. https://doi.org/10.1111/j.1537-2995.2008.01966.x

[61] Blanco, S., Balangers, M.C., Valle, M.C., Montini, O.L., Carrizo, L.H. and Gallego, S.V. (2016) Usefulness of Nucleic Acid Testing of Reduces Risk of Hepatitis B Virus Transfusion-Transmitted Infection in Argentina: High Rate of Recent Infections. Transfusion, Epub.

Submit or recommend next manuscript to OALib Journal and we will provide best service for you:

- Publication frequency: Monthly

- 9 subject areas of science, technology and medicine

- Fair and rigorous peer-review system

- Fast publication process

- Article promotion in various social networking sites (LinkedIn, Facebook, Twitter, etc.)

- Maximum dissemination of your research work

Submit Your Paper Online: Click Here to Submit

Or Contact service@oalib.com 